\title{
Study on the Training Mode Innovation of Career-creating Talents Majoring in Business Management
}

\author{
Niu Xiaomeng ${ }^{1}$ \\ ${ }^{1}$ Shandong Yingcai University, Shandong, Jinan, 250104
}

Keywords: Business management; Entrepreneurship; Training mode of talents

\begin{abstract}
Along with the continuous development of domestic economic system, training mode of career-creating talents majoring in business management is reformed gradually. In the major of business management, it is mainly reflected on the education of innovation. Presently, many problems exist in the innovative education of career-creating talents majoring in business management, such as the unclear target location of education, the inconformity between the setting up of innovative courses and the system of domestic economy and environment, the loss of the characteristics of entrepreneurship and innovative education etc. By drawing lessons from foreign successful cases in teaching and training, we'd strengthen basic professional education in the training of career-creating talents majoring in business management. Moreover, we'd attach importance to cultivating the students' positive attitude, effective behavior and employing the right skills in entrepreneurship. Only improve fundamentally the career-creating talents' personal accomplishment, can we cultivate career-creating talents of high level.
\end{abstract}

\section{Introduction}

Training mode of talents is the system that integrates all the elements relevant to talents training into a system. The system can be referred to by corresponding teachers and staffs on teaching management in the whole teaching activity, which would result in more simple and convenient teaching operation, as well as more efficient and systematic teaching scheme. The training mode of talents is mainly consisted of teaching concept, teaching thought, training objective and curriculum system, etc. To cultivate excellent innovative career-creating talents, we'd have a deep understanding of shortcomings existed in traditional training mode of career-creating talents and we'd also deeply understand the meaning and connotation of innovative career-creating talents. Only in this way, can we optimize relevant theories more systematically, and seek out the reasonable mode for the training of innovative career-creating talents and corresponding effective measures.

\section{Shortcomings existed in traditional training mode of career-creating talents majoring in business management}

At present, the setting of the major business management is not very scientific, and personnel trained are common. From the professional point of view, they do not have outstanding characteristics and graduates cultivated are all in the same key, who fail to meet the requirements of talents for the business enterprise. Shortcomings existed in traditional training mode of career-creating talents majoring in business management are as follow.

In recent years, although many universities have gradually realized the importance of 
cultivating students' personal ability, education for most majors of business management are still in the stage of infusing theories and simple cases discussion. As for the cultivation of professional talents majoring in business management, it actually relates to the training of personal ability. At present, education for the major business management in nearly all universities attach more importance to cultivating students' independent ability to analyze problems, rather than cultivating their ability to identify problems; they also pay more attention to cultivating students' ability to cope with problems with robust methods rather than cultivating their ability to have courage in shouldering risks individually.

The career-creating spirit refers to entrepreneur's ability in organizing the establishment of enterprise and the management of enterprise. This is an important, invincible and special production factor. The ability of career-creating includes not only the entrepreneur's ability, but also the spirits of adventure, integrity, efficiency, dedication and cooperation, etc., which should be possessed by the innovative career-creating talents.

According relevant survey: 1 of 16 men in the United States may have the career-creating spirit; 1 of 26 men in Europe is likely to have career-creating spirit; 1 of 36 people in Japan may have career-creating spirit; and the ratio in China is 1 of 200. Such findings undoubtedly serve as loud wake-up call for us. With soaring ambition, graduates nowadays are eager to go to large-scale companies and are unwilling to be admitted to small ones, let alone knowledge on career-creating.

Now the world develops steadily in constant change, so the ability to respond to and detect the changes is also one of the abilities that should be possessed. The operations of an enterprise is largely determined by the reaction speed to environmental changes, and an enterprise can beat the others in competition if it can seize the chance firstly in the reaction speed to environmental changes. Enterprise management itself has no specific pattern, because the environment of market changes all the time. Therefore, as an enterprise and its manager, being subtly aware of the changes in market environment is the ability that should also be possessed. However, by making a general survey of the status quo of career-creating talents cultivation for the major of business management, it can be found that relevant education attaches more importance to students' knowledge on the operation and management of different departments within an enterprise, rather than cultivating students' subtle insight for the enterprise and the external environment of the market, as well as the strain capacity to corresponding situations. According to the actual situation of an enterprise, many problems encountered by most enterprises are caused by their long and slow response to the external environmental changes.

Today, economy is developing towards the service-oriented type and each enterprise is moving forward to the trend of information-intensive type. As these two types of development has the trend of accelerating, new requirements have been put forward for the education of career-creating talents majoring in business management. Information technology shall be carried out actively in the departments such as finance, marketing, accounting and management etc., so as to continuously collect, transfer and use such information. In the market environment nowadays, the competitive ability of an enterprise largely depends on the use and use ratio of information technology. In the education of career-creating talents majoring in business management, the only several courses on information technology is not enough.

\section{The connotation of career-creating talents majoring in business management}

In view of the disadvantages existed in the traditional education modes of career-creating talents majoring in business management, all colleges and universities are gradually carrying out the innovative education. Innovative education covers the following contents [2]: (1) Cultivate students' 
consciousness of innovation, which also refers to setting up students' goals, exert students' potential force and release student's passion for innovation. (2) Cultivate students' thinking or innovation, which is also known as students' ability in the process of dealing with affairs and matters by employing new methods for thinking. (3) Cultivate students' skills for innovation, which means the ability of students' behavioral skills, such as the ability of information processing and employing skills for innovation etc. (4) Cultivate students' emotion for innovation, which refers to innovating students' power for emotion. In other words, promote students' aims, improve students' sentiment and optimize students' ability for innovation, so as to have the passion for mastering skills for innovation. By Combining with professional characteristics, cultivation for career-creating talents majoring in business management shall highlight the following several aspects:

In teaching for the major business management in institutions of higher learning, students' independent consciousness shall be cultivated so as to protect their enthusiasm in exploring the aims with freedom. Therefore, every student would have a free and broad space for development, so as to cultivate students' subject consciousness and the spirit of freedom. When it comes to freedom, it itself includes the freedom of thought, development space and fully realization of value. Exploring the enthusiasm for oneself is also the foundation for innovative ability and spirit.

In market economy, competition is one of the basic rules and is also the lifeline. Competition can stimulate people's energy, and also inspire man's motivation for innovation. At the same time, competition is closely linked with cooperation. The main characteristics of the modern market economy tend to be more close connection between different courses, and the combination between different knowledge and technologies. This kind of phenomenon indicates that the limitation of individual's knowledge is constantly being broken. Teamwork has become a necessary means in our competition. Therefore, in cultivation of career-creating talents majoring in business management, we'd focus on students' consciousness for competition and ability for cooperation.

It can be seen from the knowledge structure that talents on business management shall not only possess profound professional attainments and broad academic vision, but also have rich knowledge of humanities and social science. That is to say, we should not only possess the knowledge on business management, but also know about the knowledge in local conditions and customs, politics and economics, and human geography etc. As for the structure of ability, only talents with the ability of recombination can be outstanding in the competition of business management in the international market.

\section{Ways and measures for the cultivation of career-creating talents majoring in business management}

Along with the arrival of the era new economy, managers with talents of new-typed management is in high demand. As for the students majoring in business management, possessing the innovative spirit and cultivating their innovative ability appears especially crucial. It is of no time to delay as to how to reform the teaching content and modes so as to endow the students with the ability for innovation.

Attaching importance to the development of students' individual character and students' quality of innovation

To cultivate students' quality of innovation, we must firstly change the concept of neglecting individuality and laying emphasis to generality, and concern more about students' peculiarity in personal quality [3].In the traditional teaching mode, the same teaching material, teaching plans and teaching methods are applied to all the students, thus resulting in the sameness of all the students trained. However, all the students are different in individual character, psychological characteristics, 
knowledge structure, and learning methods. Therefore, in order to cultivate students' quality of innovation, we'd pay more attention to the development of students' personality in the process of teaching and give students a wide range of knowledge and a free learning space. Thus, the students would treat study as an interest and a method to grasp knowledge.

Reform the content and system on teaching, and add more courses on innovative career-creating

As for courses, we'd optimize students' learning system by reforming the courses on business management, so that the new course system would pay more attention to improving students' knowledge accomplishment and offering the students with more choices for the courses learned by them. By breaking through the boundaries of traditional courses and paying attention to the combination of courses, we'd treat the series of ability-oriented courses as the new curriculum system and introduce the advanced theory on management.

Reforming teaching methods

The traditional teaching methods can not meet the demands of management for modern enterprises, and it is also difficult to cultivate the students' consciousness and ability of innovation. In the present environment of market economy, the enterprises pay more attention to graduates' ability of collaboration, communication, practice and innovation. In order to meet the demands of such enterprises, it is required that we'd innovate boldly and reform the present teaching methods. Thus, in the course of teaching, more students can feel the heart-felt fun of knowledge learning and relevant students' passion can be initiated, so as to improve their practical ability and comprehensive quality.

Establishing innovation-type team for teaching

Only the innovation-type team for teaching can cultivate the innovation-type talents. The innovation-type teachers should possess advanced teaching theories and methods, the ability to meet an emergency, being brave in exploration and innovation, the ability to gain and transfer innovation-type knowledge and the attitude to encourage students in innovation. Only integrate such teachers into a team, can we effectively cultivate the innovation-type talents.

Constructing the evaluation system that is conductive to training students' ability of innovation The traditional evaluation system can influence students' development in reverse thinking and propositional thinking and the students would lack the ability and consciousness in innovation. Only change the traditional evaluation system and set up the new evaluation system that is conductive to cultivate students' ability and consciousness of innovation, can we be promoted in cultivating students' ability of innovation. [4].Firstly, we'd change it from the result-oriented evaluation to process-oriented evaluation, and it shall pay more attention to the student's process of mentality, emotion, and understanding rather than the results. Then, we'd transform single evaluation criteria into a diversified evaluation standard. Students shall be evaluated integrally with diversified standards from the aspects of their classroom performance, student experience, participation degree of classroom activities and so on. We'd encourage students in bold innovation instead of caring only about the result.

\section{Conclusions}

In order to satisfy the career-creating talents' requirements in the major business management, many universities of high learning have reformed the training of career-creating talents in the major business management, and attached more importance to the cultivation of innovation-type career-creating talents. Through the reform of education system, teachers' ability of innovation has been improved and students' quality and ability for innovation have been integrally promoted, 
which laid a solid foundation for students' future.

\section{Acknowledgements}

Project: project for the study on the reform of vocational teaching and education in Shandong Province( 2015220)

\section{References:}

[1] Lin Jianying. Research on the training mode of Higher Vocational and technical college management professional and technical talents [J]. Journal of Hubei Radio and TV University, 2013,33 (11): 27-28.

[2] Ma Hongli, Ma Choi. [J]. China Chapter, analysis of business management talents employment perspective of higher vocational training based on 2012 (36): 107-108.

[3] Song Li. The reform of the talent training mode of industrial and commercial enterprises [J]. Chinese and foreign entrepreneurs, 2014, (4): 228-228239.

[4] Han Honglei. Vocational College of industry and Commerce Management Professional School enterprise cooperation talent training mode construction [J]. modern marketing, 2015, (6): 69-70. 